\title{
A rapid, simple, and highly efficient method for VIGS and in vitro-inoculation of plant virus by INABS applied to crops that develop axillary buds and can survive from cuttings
}

Qili Liu ${ }^{1,2,3{ }^{\dagger}}$, Kedong $\mathrm{Xu}^{4 \dagger}$, Lun $\mathrm{Yi}^{2}$, Yalin $\mathrm{Hou}^{2}$, Dongxiao $\mathrm{Li}^{3}$, Haiyan $\mathrm{Hu}^{3}$, Feng Zhou ${ }^{3}$, Puwen Song ${ }^{3}$, Yongang $\mathrm{Yu}^{3}$, Qichao $\mathrm{Wei}^{3}$, Yuanyuan $\mathrm{Guan}^{3}$, Ping $\mathrm{Hu}^{3}$, Ruifang $\mathrm{Bu}^{3}$, Eryong $\mathrm{Chen}^{3}$, Xiaojia Su${ }^{3}$, Honglian $\mathrm{Li}^{1^{*}}$ and Chengwei $\mathrm{Li}^{2,3,5^{*}}$

\begin{abstract}
Background: Virus-induced gene silencing (VIGS) is one of the most convenient and powerful methods of reverse genetics. In vitro-inoculation of plant virus is an important method for studying the interactions between viruses and plants. Agrobacterium-based infiltration has been widely adopted as a tool for VIGS and in vitro-inoculation of plant virus. Most agrobacterium-based infiltration methods applied to VIGS and virus inoculation have the characteristics of low transformation efficiencies, long plant growth time, large amounts of plant tissue, large test spaces, and complex preparation procedures. Therefore, a rapid, simple, economical, and highly efficient VIGS and virus inoculation method is in need. Previous studies have shown that the selection of suitable plant tissues and inoculation sites is the key to successful infection.

Results: In this study, Tobacco rattle virus (TRV) mediated VIGS and Tomato yellow leaf curl virus (TYLCV) for virus inoculation were developed in tomato plants based on the agrobacterium tumefaciens-based infiltration by injection of the no-apical-bud stem section (INABS). The no-apical-bud stem section had a "Y- type" asymmetric structure and contained an axillary bud that was about $1-3 \mathrm{~cm}$ in length. This protocol provides high transformation (56.7\%) and inoculation efficiency (68.3\%), which generates VIGS transformants or diseased plants in a very short period (8 dpi). Moreover, it greatly reduces the required experimental space. This method will facilitate functional genomic studies and large-scale disease resistance screening.
\end{abstract}

Conclusions: Overall, a rapid, simple, and highly efficient method for VIGS and virus inoculation by INABS was developed in tomato. It was reasonable to believe that it can be used as a reference for the other virus inoculation methods and for the application of VIGS to other crops (such as sweet potato, potato, cassava and tobacco) that develop axillary buds and can survive from cuttings.

\footnotetext{
*Correspondence: honglianli@sina.com; Icw@haut.edu.cn

${ }^{\dagger}$ Qili Liu and Kedong Xu contributed equally to this work.

1 College of Plant Protection, Henan Agricultural University,

Zhengzhou 450002, China

${ }^{5}$ College of Biological Engineering, Henan University of Technology,

Zhengzhou 450001, China

Full list of author information is available at the end of the article
}

(C) The Author(s) 2021. Open Access This article is licensed under a Creative Commons Attribution 4.0 International License, which permits use, sharing, adaptation, distribution and reproduction in any medium or format, as long as you give appropriate credit to the original author(s) and the source, provide a link to the Creative Commons licence, and indicate if changes were made. The images or other third party material in this article are included in the article's Creative Commons licence, unless indicated otherwise in a credit line to the material. If material is not included in the article's Creative Commons licence and your intended use is not permitted by statutory regulation or exceeds the permitted use, you will need to obtain permission directly from the copyright holder. To view a copy of this licence, visit http://creativecommons.org/licenses/by/4.0/. The Creative Commons Public Domain Dedication waiver (http://creativeco mmons.org/publicdomain/zero/1.0/) applies to the data made available in this article, unless otherwise stated in a credit line to the data. 
Keywords: Virus-induced gene silencing (VIGS), In vitro-inoculation of plant virus, Agrobacterium-based infiltration, Injection of no-apical-bud stem sections (INABS)

\section{Background}

Virus-induced gene silencing (VIGS) is one of the most convenient and powerful methods of reverse genetics [1], and it is increasingly widely used to study plant gene functions $[2,3]$. Several viruses have been developed for use in VIGS [2, 4]. One of these viruses, the Tobacco rattle virus (TRV), has a broad host range and has been used in VIGS as a vector to study gene function in many species, including Solanum spp. [5-9], Nicotiana spp. [10-12], Arabidopsis thaliana [13], Papaver somniferum [14], Gossypium hirsutum [15], Amaranthus tricolor [16], Triticum aestivum, and Zea mays L. [17]. The molecular mechanisms of VIGS have been well studied, and the development and improvement of VIGS is presently focused on the creation of new viral constructs for different plant species, the search for new reporter genes to control VIGS efficiency, and the development of new, efficient infection methods [1].

In vitro-inoculation of plant virus is an important method for studying the interaction between viruses and plants. Agrobacterium-based infiltration has been widely used as an inoculation tool for the infectious clones of plant viruses. The Tomato yellow leaf curl virus (TYLCV) belongs to the genus Begomovirus, within the family Geminiviridae. It is distributed worldwide and rated as the third most important plant virus [18]. TYLCV is a typical member of geminiviruses, and its inoculation methods are similar to those of most DNA viruses. Several methods have been developed to test the infectivity of TYLCV and to understand the mechanisms of TYLCV resistance in plants; these include natural field infection, whitefly inoculation in cages, leaf or stem agroinfiltration, and biolistic inoculation [19-21].

However, most methods used for VIGS infection and inoculation of DNA virus have low transformation efficiency and require long plant growth times, large amounts of plant tissue, large test spaces, and complex preparation procedures. Agrobacterium tumefaciensbased infiltration is often used for VIGS and mechanical inoculation for virus inoculation, but it typically takes a long time for symptoms to appear [22]. Studies have shown that the selection of suitable plant tissues and inoculation sites is the key to successful infection. Commonly used tissues include the meristems of seedlings [23], three-week-old micro-shoots [24], and the stems or petioles of 4-6 leaf stage plants [25]. However, the use of such sites is complicated and time-consuming, increasing the operational complexity of inoculation [23-25]. Therefore, a rapid, simple, economical, and highly efficient VIGS and virus inoculation method is in need. In this study, TRV mediated VIGS and TYLCV for virus inoculation were developed in tomato plants based on the agrobacterium tumefaciens-based infiltration by injection of the no-apical-bud stem section (INABS). This protocol gives a high transformation and inoculation efficiency and can generate transformants or diseased plants in a very short period of time. Moreover, it greatly reduces the required experimental space. This method will facilitate functional genomics studies and large-scale disease resistance screens.

\section{Results}

The no-apical-bud stem section is optimal for VIGS and in vitro-inoculation of plant virus

VIGS

The phytoene desaturase (PDS) gene as a reporter gene proved the efficacy of the TRV mediated VIGS system by INABS in tomato. About $100-200 \mu$ l of agroinfiltration liquid harboring empty vector control TRV $(A$. tumefaciens carrying pTRV2 and pTRV1), treatment TRV-SIPDS (A. tumefaciens carrying pTRV2-SIPDS and pTRV1) could be slowly injected into the bare stem of no-apical-bud stem section using a plastic syringe and needle (Fig. 1a). A film of agroinfiltration liquid formed at the top of the injected stem sections when infiltration liquid had filled the entire bare stem (Fig. 1b). No-apicalbud stem sections without agrobacterium injection were used as wild-type (WT) controls. Six days after inoculation, bleaching started to become evident in portions of the mesophyll tissue in the axillary buds transformed with TRV-SlPDS. About 10 days after inoculation, the axillary buds of treatment TRV-SIPDS had grown out, and widespread bleaching was evident in the grown leaves (Fig. 1c-1 and c-2). Bleaching of mesophyll tissue were not observed in TRV and WT control. $\mathrm{H}_{2} \mathrm{O}_{2}$ production increased in leaves that emerged from the axillary bud of the no-apical-bud stem section of treatment TRV-SlPDS (Fig. 1e). The expression of PDS gene of the grown bleaching leaves treated with TRV-SIPDS was significantly down-regulated at 8 days after inoculation (Fig. 2). The grown axillary buds of treatment TRV-SIPDS showed a high gene silencing success rate $(56.7 \%$, Table 1$)$ based on qRT-PCR analysis. 

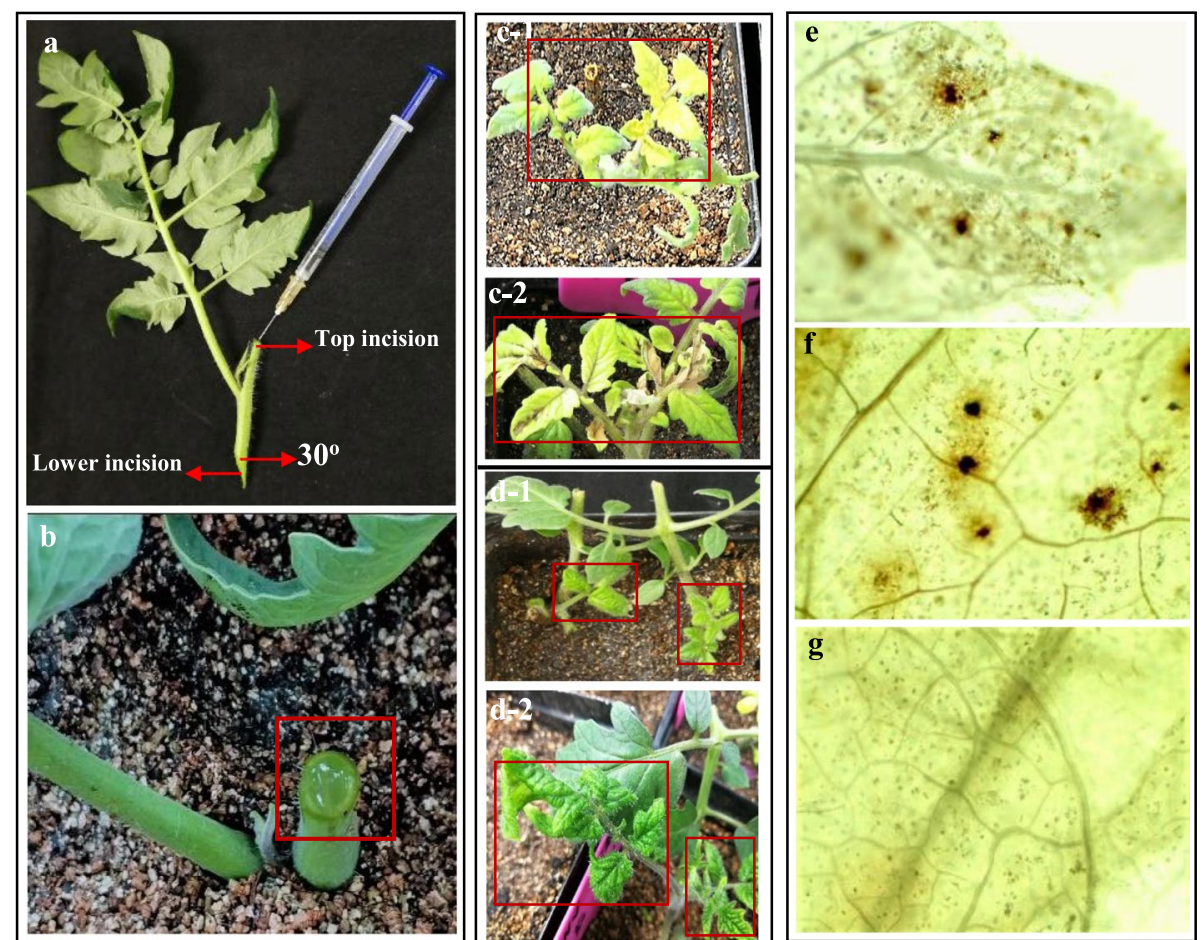

Fig. 1 Injection of no-apical-bud stem sections (INABS) for tomato. a the tomato no-apical-bud stem section and Agrobacterium injection; $\mathbf{b}$ a film of agroinfiltration liquid formed at the top incision of the injected bare stem; $\mathbf{c}-\mathbf{1}$ and $\mathbf{c}-\mathbf{2}$ the grown tomato axillary buds transformed with TRV-SIPDS (A. tumefaciens carrying PTRV2-SIPDS and pTRV1) showed leaf bleaching; $\mathbf{d}-\mathbf{1}$ and $\mathbf{d}-\mathbf{2}$ the axillary buds of tomato showed obvious TYLCV infection symptoms; $\mathbf{e}-\mathbf{g ~} \mathrm{H}_{2} \mathrm{O}_{2}$ production was detected in leaves that emerged from the axillary bud of the no-apical-bud stem sections infected with TRV-SIPDS (e) and TYLCV (f); $\mathbf{g}$ WT control groups for $(\mathbf{e})$ and $(\mathbf{f})$

\section{Virus inoculation in vitro}

The INABS method achieved the infection of DNA virus. In the case of an important DNA virus, TYLCV was inoculated into tomato no-apical-bud stem sections as described above, and TYLCV infection symptoms appeared 3 days after inoculation. The young leaves of axillary buds began to show crinkling and yellowing. At $10 \sim 12 \mathrm{dpi}$, the axillary buds had grown out and showed obvious TYLCV infection symptoms (Fig. $1 \mathrm{~d}-1$ and d-2). Consistent with this observation, $\mathrm{H}_{2} \mathrm{O}_{2}$ production increased in leaves that had emerged from the axillary buds of INABS - a known response of plant cells to virus infection (Fig. $1 \mathrm{f}$ ). qRT-PCR analysis showed that the young leaves were infected by TYLCV and the incidence of TYLCV diseases was $27.7,68.3,61.0 \%$ at $4 \mathrm{dpi}, 8 \mathrm{dpi}$ and $12 \mathrm{dpi}$ respectively (Table 1). $\mathrm{H}_{2} \mathrm{O}_{2}$ and TYLCV were not detected in the young leaves of WT control, indicating the no-apicalbud stem sections were not inoculated with TYLCV.

\section{Optimization of bacterial optical density (OD) and INABS time}

Bacterial OD and INABS time were optimized. Using different combinations of INABS time points $(4,8$, and 12 d) and bacterial concentrations (OD600 of 0.5, 1.0, and 1.5), an agroinfiltration liquid with OD600 of 1.0 and an INABS time point of $8 \mathrm{~d}$ resulted in significantly higher VIGS efficiency (56.7\%) and TYLCV inoculation rate $(68.3 \%)$ by symptoms observation and qRT-PCR analysis (Table 1). An OD600 of 1.0 and an INABS time of 8 $\mathrm{d}$ were therefore adopted to achieve the highest transformation efficiency and success rate of virus inoculation (Table 1).

\section{INABS promotes faster virus infection and VIGS process}

Parallel Agrobacterium-mediated virus infection and VIGS experiments using three different inoculation methods (INABS, infiltration of the dorsal leaf and injection of the basal stem) showed that the INABS method outperformed the other inoculation methods and sites (Table 2). Compared with the dorsal leaf or stem base, the no-apical-bud stem section could hold a higher volume of agroinfiltration liquid (100-200 $\mu \mathrm{l})$, thus increasing the infection success rate. The INABS method developed here required only $10-12 \mathrm{~d}$ and $8-10 \mathrm{~d}$ for the appearance of leaf bleaching and disease symptoms, respectively. It produced symptoms much more rapidly than the other two methods: infiltration of the dorsal leaf (30-50 


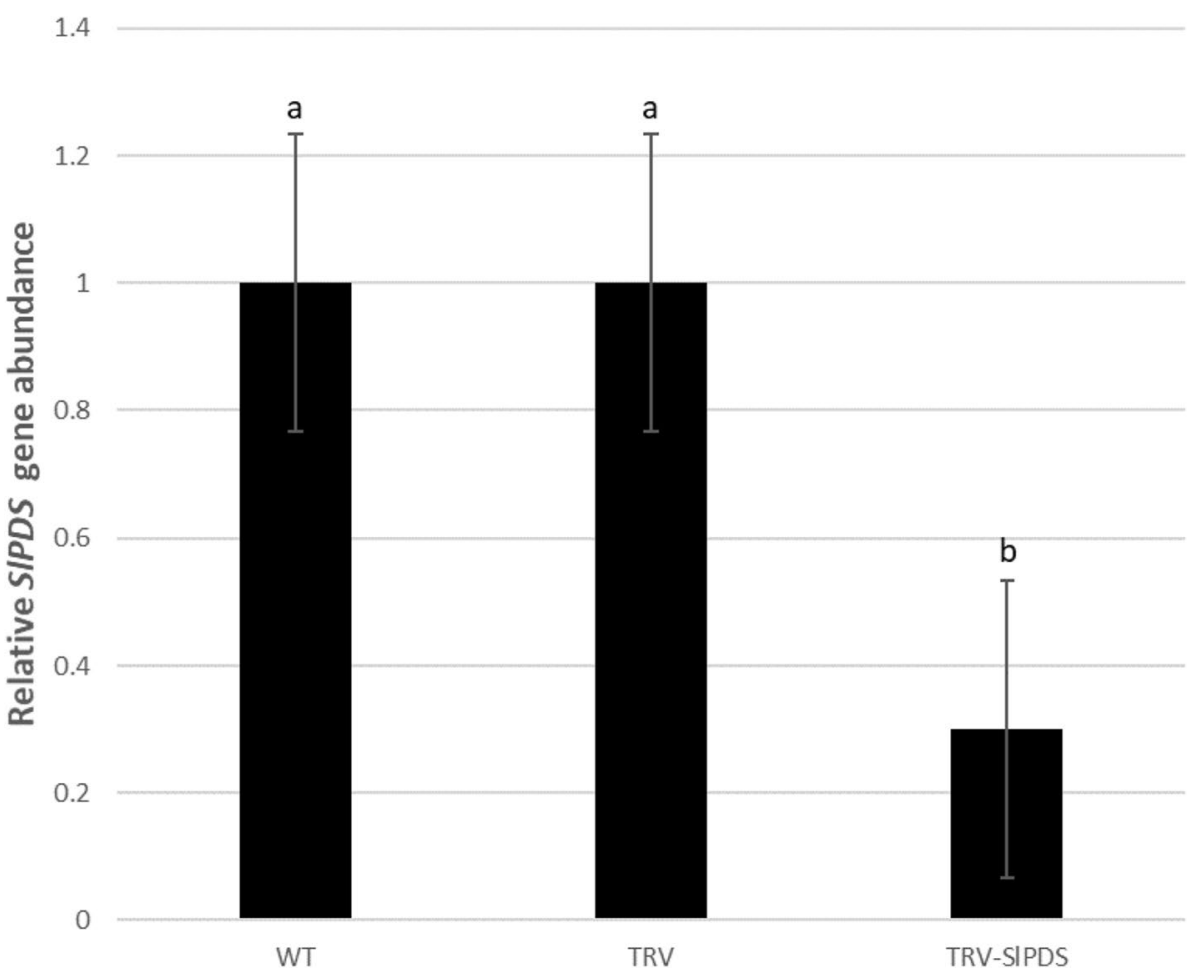

Fig. 2 Quantitative qRT-PCR analysis of TRV-mediated VIGS of the PDS gene in tomato leaves by injection of the no-apical-bud stem section (INABS). WT: wild-type plants; TRV: VIGS control plants infected by Agrobacterium tumefaciens carrying pTRV 2 and pTRV1; TRV-SIPDS: PDS-silenced plants infected by A. tumefaciens carrying pTRV2-SIPDS and pTRV1. Values (means \pm SD are the averages of three independent experiments, and significant differences $(P \leq 0.05)$ among treatments in each group are indicated by different letters (Duncan's multiple range test)

$\mathrm{d}$ and $23-45 \mathrm{~d})$ and injection of the basal stem (35-60 d and $30-45 \mathrm{~d})$.

\section{INABS rapidly identifies TYLCV-resistant tomato varieties} We next tested whether the INABS method could be used for rapid assessment of TYLCV resistance using three tomato varieties with different degrees of resistance to TYLCV: 'Money Maker' (with TYLCV-susceptible

Table 1 Effects of bacterial concentration and inoculation time on the efficiency of INABS infiltration

\begin{tabular}{llll}
\hline Inoculation time & $\begin{array}{l}\text { VIGS efficiency of the PDS gene (\%) and } \\
\text { TYLCV inoculation success rate (\%) after } \\
\text { infiltration of } \text { Agrobacterium at different } \\
\text { concentrations }\end{array}$ \\
\cline { 2 - 4 } & $\mathbf{0 . 5}^{\left(\mathbf{O D}_{\mathbf{6 0 0}}\right)}$ & $\mathbf{1 . 0}\left(\mathbf{O D}_{\mathbf{6 0 0}}\right)$ & $\mathbf{1 . 5}\left(\mathbf{O D}_{\mathbf{6 0 0}}\right)$ \\
\hline $4 \mathrm{dpi}$ & $11.3 \mathrm{~b} / 16.7 \mathrm{~b}$ & $17.7 \mathrm{c} / 27.7 \mathrm{~b}$ & $16.0 \mathrm{~b} / 23.3 \mathrm{~b}$ \\
$\mathbf{8 d p i}$ & $21.7 \mathrm{a} / 34.3 \mathrm{a}$ & $56.7 \mathrm{a} / 68.3 \mathrm{a}$ & $30.7 \mathrm{a} / 56.0 \mathrm{a}$ \\
$12 \mathrm{dpi}$ & $17.7 \mathrm{~b} / 29.3 \mathrm{a}$ & $45.0 \mathrm{~b} / 61.0 \mathrm{a}$ & $28.3 \mathrm{a} / 55.0 \mathrm{a}$
\end{tabular}

Note: Each value represents the mean transformation efficiency or success rate of virus infection $(n=3)$. Within a column, significant differences $(P \leq 0.05)$ among treatments are indicated by different letters (Duncan's multiple range test) tomato varieties), 'Zhongshu 4' (with general susceptibility to TYLCV), and 'Jinpeng 322' (with highly TYLCVresistant variety). The three varieties showed different levels of resistance to TYLCV infection in our experiment (Fig. 3). 'Jinpeng 322' took the longest time to show symptoms $(\sim 27 \mathrm{dpi})$ and showed high resistance to TYLCV (27.7\% incidence). 'Zhongshu 4' showed symptoms after 10 days and had an incidence of $75.0 \%$. 'Money Maker' showed high susceptibility ( $89.7 \%$ incidence, symptoms $\sim 9$ days after inoculation). In addition to identify the varietal susceptibility to TYLCV, INABS also greatly reduced the required experimental space and permitted disease resistance evaluation at the seedling stage.

\section{Discussion}

In this study, a rapid, simple, and highly efficient method for INABS was developed for VIGS and plant DNA virus inoculation in tomato. The method greatly facilitates VIGS progress and offers a feasible strategy for identifying TYLCV-resistant varieties that are suitable for inoculation in VIGS and for the initial screening of DNA virus-resistant plants under controlled conditions. We also observed that agroinfiltrated stem sections with water films had a higher efficiency than those without 
Table 2 Comparison of the virus infection and VIGS process of three inoculation methods

\begin{tabular}{|c|c|c|c|c|c|c|}
\hline $\begin{array}{l}\text { Inoculation } \\
\text { methods }\end{array}$ & Inoculation sites & $\begin{array}{l}\text { Volume of } \\
\text { agroinfiltration } \\
\text { liquid that can enter } \\
\text { plants }(\mu \mathrm{l})\end{array}$ & $\begin{array}{l}\text { Time required to } \\
\text { obtain VIGS plants } \\
\text { (d) }\end{array}$ & $\begin{array}{l}\text { Success rate } \\
\text { of VIGS (\%) }\end{array}$ & $\begin{array}{l}\text { Time required to } \\
\text { obtain symptomatic } \\
\text { plants (d) }\end{array}$ & $\begin{array}{l}\text { Inoculation } \\
\text { success rate of } \\
\text { TYLCV (\%) }\end{array}$ \\
\hline INABS & $\begin{array}{l}\text { no-apical-bud stem } \\
\text { section }\end{array}$ & $100-200$ & $10-12$ & 60 & $8-10$ & 72 \\
\hline $\begin{array}{l}\text { Infiltration the dorsal } \\
\text { leaf }\end{array}$ & back of tender leaf & $10-50$ & $30-50$ & 30 & $23-45$ & 40 \\
\hline $\begin{array}{l}\text { Injection of the } \\
\text { basal stem }\end{array}$ & $\begin{array}{l}\text { base of stem } \\
(\sim 2-3 \mathrm{~cm} \text { from the } \\
\text { soil surface) }\end{array}$ & $20-30$ & $35-60$ & 36 & $30-45$ & 48 \\
\hline
\end{tabular}

water films (data not shown). This may be because the water film persisting for a certain period of time was filled with agroinfiltration liquid and allowed for more efficient infiltration of the epidermal cells, thereby increasing the ratio of infiltrated cells. Compared to other traditional methods of inoculation, this rapid assay has many advantages, including the rapid onset of viral symptoms, relatively short plant growth time, reduced space requirements, and the ability to screen for TYLCV resistance in tomato. It is also could be a useful tool for studying viral biology in tomato and other crops (such as sweet potato, potato, cassava and tobacco) that develop axillary buds and can survive from cuttings.

There are many ways to improve the efficiency of VIGS. Examples include infiltration of lower leaves with a needleless syringe [26], pouring inoculum from the apical region and soaking wounded stems and leaves randomly pierced with a sterilized needle [16], infiltration of the abaxial side of both cotyledons $[9,15]$, vacuum and co-cultivation agroinfiltration of germinated seeds [17], carpopodia of young fruit attached to the plant after pollination [5], soil adjacent to the plant roots (this method

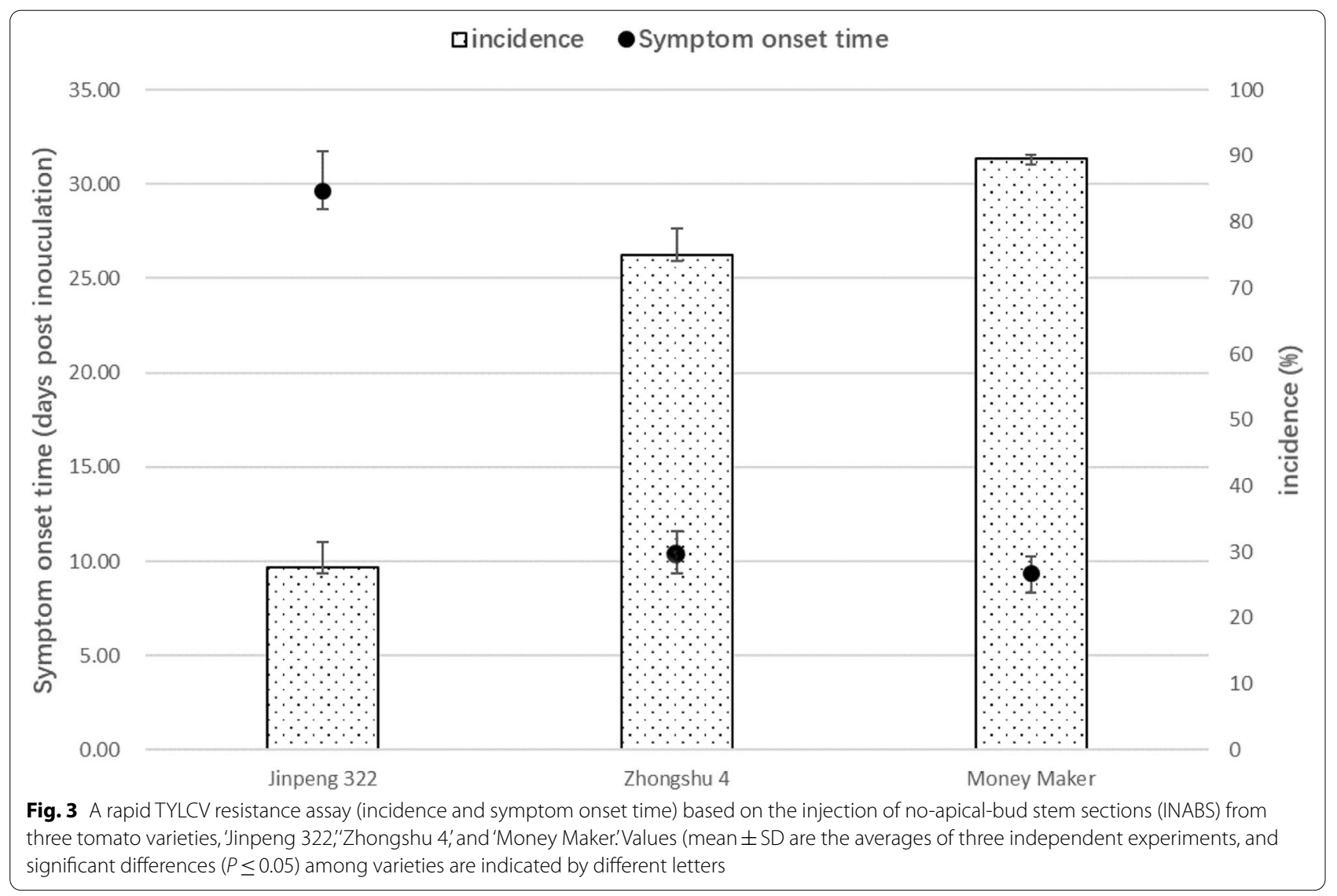


is called "agrodrenching") [10] and infiltration at three different stages of seedling development [14]. It typically requires $\sim 15-60$ days to obtain transformants with these methods $[1,17]$. With the INABS method, the time period from inoculation to obtaining the target plants was reduced greatly ( $10-12$ days). The injected stems with water films formed at the top incision of the injected bare stem exhibited a higher transformation efficiency than those without water films. It may be that the agroinfiltration water film provides extra volume that allows more time for the Agrobacteria to enter and infect the axillary buds. Compared with other previously reported methods, INABS has a relatively higher VIGS efficiency and infection efficiency of TYLCV. In addition, compared with other infiltration sites, the no-apical-bud stem was more suitable for inoculation and virus infection because it could accept a high volume of agroinfiltration liquid, which rapidly entered the susceptible young axillary buds.

The mechanical inoculation of viruses into plants has been studied for years. Plant viruses are typically inoculated by rubbing an inoculant onto the surface of the leaf: plant material known or suspected to be virus infected, a solution of virus preparation, or an infectious clone [21]. Inoculation with a DNA virus usually requires a needle to inject bacterial cultures harboring an infectious clone of the virus into the stems or petioles of plants at the 4-6 leaf stage [25]. Here, injection of no-apical-bud stem sections induced infection symptoms in a short period of time, probably because axillary buds contain much younger cells that are more susceptible to virus infection. Therefore, no-apical-bud stems are well-suited for virus inoculation compared with other plant tissues that are mechanically inoculated using previously described methods.

The artificial pruned axillary buds, which affects the growth rate, and the susceptibility of young leaves to the virus are two key success factors for INABS. The growth rate of axillary buds is regulated by plant hormones. Sae et al. proposed a regulatory mechanism by which plant hormones control apical dominance [27]. When apical buds are present, indoleacetic acid (IAA) derived from apical buds activates IAA-inducible genes and represses the activity of isopentenyl transferase (IPT) in nodes, indirectly promoting abscisic acid (ABA) biosynthesis in nodes and axillary buds. ABA then activates the expression of ABA-inducible genes, inhibiting the outgrowth of axillary buds. Decapitation removes the IAA supply from apical buds, causing IAA deficiency in the nodes. IPT is expressed in nodes and is involved in cytokinin production. Cytokinin from the nodes then enters the axillary buds and promotes their outgrowth. The no-apical-bud stem section has a "Y-type" asymmetric structure that enriches cytokinin in the axillary buds, and the lateral leaf performs photosynthesis to provide energy for the axillary buds. The " $Y$ " structure ensures the survival of no-apical-bud stems and facilitates the virus infection of axillary buds. Based on the general principles of INABS, it is reasonable to believe that it can be applied to other crops that develop axillary buds and can survive from cuttings (such as sweet potato, potato, cassava and tobacco).

\section{Conclusion}

Overall, INABS was developed as a rapid, simple, and highly efficient method for VIGS and virus inoculation in tomato. The core of this method was the no-apicalbud stem section with a "Y- type" asymmetric structure and an axillary bud that was about $1-3 \mathrm{~cm}$ in length. This protocol provides high transformation and inoculation efficiency, which generates VIGS transformants (only 10-12 d for leaf bleaching) or diseased plants in a very short period (8-10 d) respectively. Moreover, it greatly reduces the required experimental space. We inferred that the method can also be used for other virus inoculation in vitro and VIGS applied to other crops (such as sweet potato, potato, cassava and tobacco) that develop axillary buds and can survive from cuttings. This method will facilitate functional genomic studies and large-scale disease resistance screening.

\section{Methods}

\section{Plant materials and selection of the no-apical-bud stem} section

The cultivated Solanum lycopersicum (tomato) variety 'Money Maker,' which is commonly used in genetic research, was planted in soil and grown in a greenhouse at $25-28^{\circ} \mathrm{C}$ for 1 month until the stems were about $35 \mathrm{~cm}$ in length.

Stem sections $(\sim 4-6 \mathrm{~cm})$ with no apical buds were removed and planted in nutritional soil (2:1 mixture of moss peat and vermiculite, PindStrup, Denmark) (Fig. 4 $\mathrm{d}$ and e) for 1-2 $\mathrm{d}$ before agroinfiltration. The no-apicalbud stem section had a "Y- type" asymmetric structure, and their upper incision was located about $2.5-3.5 \mathrm{~cm}$ from the base of the lateral branch or compound leaf. The top incision of each section was flat, whereas the lower incision was made at a $30^{\circ}$ angle. Each stem section contained an axillary bud that was about $1-3 \mathrm{~cm}$ in length (Fig. $4 \mathrm{~d}$ ).

\section{VIGS and in vitro-inoculation of plant virus by INABS VIGS}

The phytoene desaturase (PDS) gene was used to verify the efficacy of the TRV-VIGS system because of its ability to produce a distinct bleaching phenotype. Treatment TRV-SlPDS, TRV (empty vector control), and WT (no-apical-bud stem sections without agrobacterium 


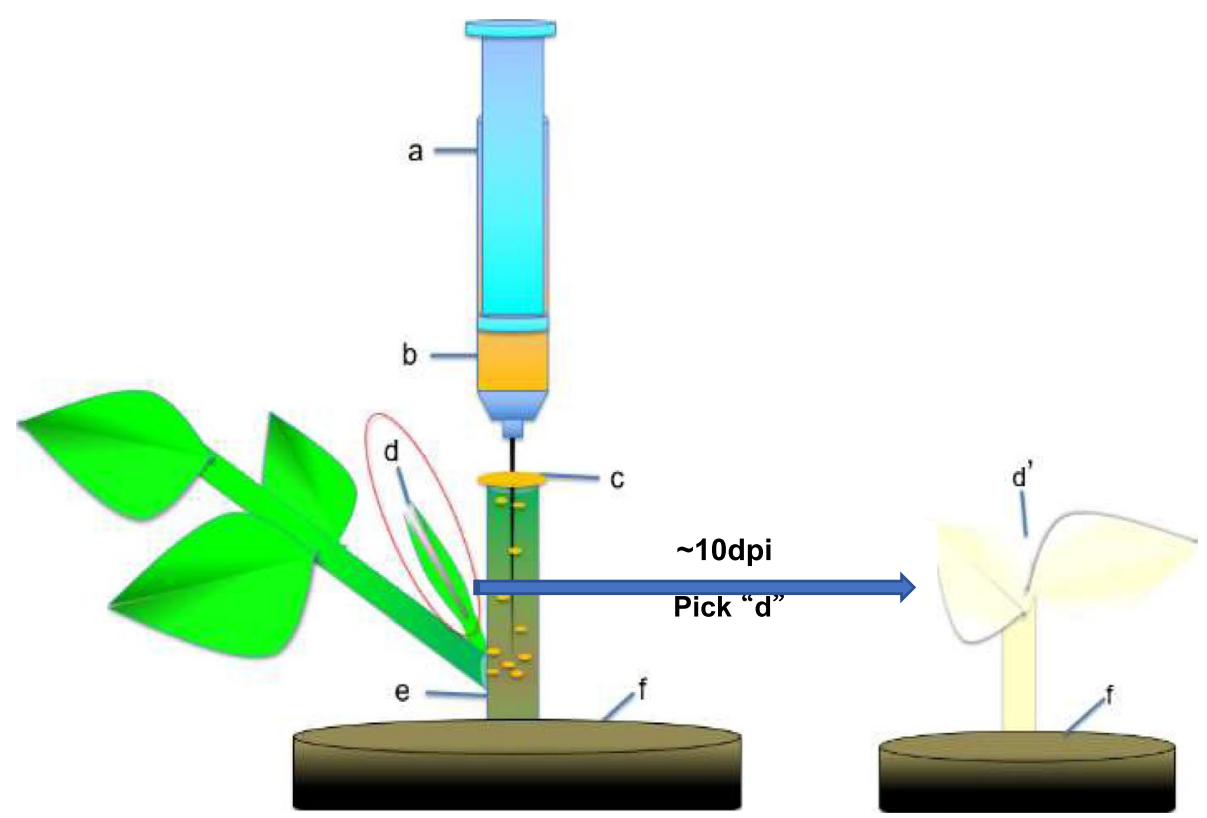

Fig. 4 The infiltration of the no-apical-bud stem section (INABS) method. a A syringe. b The agroinfiltration liquid. $\mathbf{c}$ An agroinfiltration water film formed at the top incision of the injected bare stem. $\mathbf{d}$ An axillary bud. e A no-apical-bud stem section. $\mathbf{f}$ Nutritional soil. d': An axillary bud showing infection symptoms

injection) were set up, and each treatment had one-hundred no-apical-bud stem sections. The pTRV1, pTRV2, and pTRV2-SIPDS constructs were transformed into $A$. tumefaciens strain GV3101 for further transient transformation in tomato (for vector construction details, refer to [8]). Bacterial clones carrying the constructs were cultivated overnight at $28^{\circ} \mathrm{C}$, harvested when OD600 reached $1.5-2.0$, centrifuged at $4000 \mathrm{rpm}$ for $10 \mathrm{~min}$, and re-suspended in an agroinfiltration liquid to the appropriate concentration for agroinfiltration. A 1:1 (v/v) mixture of pTRV1 and pTRV2-SlPDS agroinfiltration suspensions was prepared as TRV-SIPDS treatment.

Different Agrobacterium concentrations (OD600 0.5, 1.0, and 1.5) were tested to determine the optimal concentration for efficient transformation. In each batch, noapical-bud stem sections inoculated with an empty vector TRV (a 1:1 mixture of pTRV1 and pTRV2 agroinfiltration liquids) served as empty vector controls. The infiltration solution was prepared as follows: $41.65 \mathrm{mM} \mathrm{D}$-glucose, $100 \mathrm{mM} \mathrm{CaCl}_{2}, 100 \mathrm{mM}$ MES-KOH (pH5.6) stock solution, $0.011 \mu \mathrm{M}$ BAP, $0.01 \%$ Silwet L-77, $0.05 \mathrm{mM} \mathrm{MgCl}_{2}$, and $12.5 \mathrm{mM}$ AS stock solution (made with dimethylformamide, DMF). Double-distilled $\mathrm{H}_{2} \mathrm{O}$ was used to adjust the final volume to $20 \mathrm{ml}$ [28].

\section{Virus inoculation in vitro}

The infectious vector TYLCV-[CN:SH2] (Refer to [29] for details on vector construction) and the binary vector
pBINPLUS (negative control) were transferred into $A$. tumefaciens strain EHA105 by electroporation. EHA105 clones carrying the aforementioned constructs were cultivated for $24 \mathrm{~h}$ at $28^{\circ} \mathrm{C}$ in Luria-Bertani (LB) medium supplemented with appropriate antibiotics, harvested by centrifugation, and resuspended to final OD600 values of $0.5,1.0$, and 1.5 in liquid Murashige and Skoog (MS) medium supplemented with $100 \mu \mathrm{M}$ acetosyringone [24]. Different bacterial concentrations were tested to determine the optimal concentration for high transformation efficiency. Different concentrations of agroinfiltration liquid harboring the infectious clone were then injected into tomato no-apical-bud stem sections using 5-ml syringes (Fig. 4 a-e). No-apical-bud stem sections without agrobacterium injection were used as WT controls. Two treatments had one-hundred no-apical-bud stem sections respectively.

\section{Experimental operation details}

Agroinfiltration liquid for VIGS (TRV-SlPDS, TRV) or for virus inoculation in vitro (TYLCV-[CN:SH2]) was injected into tomato no-apical-bud stem sections. The needle was inserted into the upper end of the top incision, $0.5-1 \mathrm{ml}$ of the bacterial liquid was injected, and the needle was held in place for 1-2 min. The needle was pulled out slowly, and the bacterial liquid naturally formed a liquid film at the incision site (Fig. 4 c). The growth and symptoms of no-apical-bud stem sections 
were observed daily. The growing axillary buds were measured for VIGS efficiency and TYLCV inoculation success rate every 4 days based on symptoms and qRTPCR anylysis (4, 8, and $12 \mathrm{~d}$ ) after injection to evaluate the effects of transformation and inoculation.

\section{Comparison of different inoculation methods and sites}

Agroinfiltration liquid containing TRV (OD600 1.0, empty vector control of VIGS), TRV-SIPDS (OD600 1.0, treatment of VIGS) or TYLCV (OD600 1.0, treatment of virus inoculation in vitro) was injected into different parts of the tomato plants respectively: the no-apicalbud stem section, the dorsal leaf, or the basal stem. The no-apical-bud stem sections without any agrobacterium injection or infiltration were used as WT controls. Each treatment was replicated one-hundred times. Three biological repetitions were developed.

\section{INABS}

The injection of the no-apical-bud stem section is described above.

\section{Infiltration of the dorsal leaf}

Tomato seedlings at the three-true-leaf stage were used for dorsal leaf Agrobacterium infiltration. The agroinfiltration liquid was infiltrated into the back of the tomato leaves using 5 - $\mathrm{ml}$ syringes without needles.

\section{Injection of the basal stem}

Tomato seedlings at the three-true-leaf stage were used for basal stem Agrobacterium infiltration using 5-ml syringes with needles. Three sites on each stem were infiltrated.

After infiltration, the plants were grown in darkness for $48 \mathrm{~h}$ at $25-28^{\circ} \mathrm{C}$ with a relative humidity of 80-90\%. Thereafter, the stem segments were cultured in a pest-controlled greenhouse at $25-28^{\circ} \mathrm{C}$ with $70 \%$ relative humidity and a $16 \mathrm{~h} / 8 \mathrm{~h}$ light/dark photoperiod. The symptoms of VIGS and infection of TYLCV were recorded and evaluated.

\section{Total RNA and DNA extraction and qRT-PCR analysis}

Total RNA was extracted from the leaves of the wild type (non-transgenic control), pTRV1 and pTRV2 (empty vector controls), and symptomatic plants using the TRIzol reagent (Invitrogen, USA) according to the manufacturer's instructions. First-strand cDNA was synthesized using mixtures containing $2 \mathrm{mg}$ of total RNA, oligo (dT), and M-MLV Reverse Transcriptase (Promega, USA) according to the manufacturer's instructions. The cDNAs were then used as templates for quantitative RT-PCR
(qRT-PCR) with gene-specific primers outside the gene regions targeted for silencing.

Total DNA was extracted from leaves that grew from axillary buds inoculated by TYLCV. qRT-PCR was performed with SYBR Premix Ex Taq (TaKaRa, China) using an ABI Prism 7500 instrument (Applied Biosystems, USA) following the manufacturers' recommendations. The primers used for qRT-PCR are listed in supplementary materials (Table S1).

\section{$\mathrm{H}_{2} \mathrm{O}_{2}$ determination}

Inoculated leaves were stained with 3,3-diaminobenzidine $(\mathrm{DAB})[30]$ to examine the distribution and level of $\mathrm{H}_{2} \mathrm{O}_{2}$. Tomato leaves were excised from plants and placed into $20-\mathrm{ml}$ tubes, covered with a $\mathrm{DAB}-\mathrm{HCl}$ solution $(1 \mathrm{mg} / \mathrm{ml}, \mathrm{pH} 3.8)$, and incubated in a growth chamber for $8 \mathrm{~h}$ at $25^{\circ} \mathrm{C}$. When the red-brown DAB solution moved to the top of leaves via the veins, the chlorophyll of whole blades was removed by immersing the samples directly in a fixative solution (anhydrous ethanol: acetic $\operatorname{acid}=3: 1$ ) for $24 \mathrm{~h}$. Leaves staining was developed with hydrated trichloroacetaldehyde three times and observed under an optical microscope (Olympus, Japan).

\section{Identification of TYLCV-resistant tomato varieties}

Seeds of the TYLCV-susceptible tomato varieties 'Money Maker,' 'Zhongshu 4' (with general susceptibility to TYLCV; provided by the Zhengzhou Hongfeng Seed Co.) and the highly TYLCV-resistant variety 'Jinpeng 322' (provided by the Xi'an Jinpeng Seed Co.) were germinated in a growth chamber $\left(25^{\circ} \mathrm{C}\right.$, cool white fluorescent lights, $50-100 \mu \mathrm{Em}^{-2} \mathrm{~s}^{-1}$, $16 \mathrm{~h}$ light $/ 8 \mathrm{~h}$ dark photoperiod). After 1 month, when the stems were $\sim 35 \mathrm{~cm}$ in length, two-hundred no-apical-bud stem sections were harvested for each variety (one half was used for inoculation of TYLCV and the other half was used as WT control), and virus inoculation experiments were performed.

\section{Abbreviations}

VIGS: Virus-induced gene silencing; INABS: Injection of no-apical-bud stem sections; TRV: Tobacco rattle virus; TYLCV: Tomato yellow leaf curl virus; PDS: Phytoene desaturase; OD: Optical density; IAA: Indoleacetic acid; IPT: Isopentenyl transferase; ABA: Abscisic acid; LB: Luria-Bertani; MS: Murashige and Skoog; DAB: 3,3-diaminobenzidine.

\section{Supplementary Information}

The online version contains supplementary material available at https://doi. org/10.1186/s12870-021-03331-9.

Additional file 1: Table S1. Primers used for quantitative real-time fluorescence $P C R$ (qRT-PCR). 


\section{Acknowledgements}

The authors gratefully acknowledge Prof. Xueping Zhou and Associate Researcher Xiuling Yang (Institute of Plant Protection, Chinese Academy of Agricultural Sciences, China) for providing TYLCV infectious clones.

\section{Authors' contributions}

$\mathrm{QL}$ and KX designed and performed the research and wrote the paper; $\mathrm{LY}$ and $\mathrm{YH}$ performed the research. DL, HH, and FZ collected and analyzed data. PS, YY, QW, YG, PH, RB, and EC performed some tests of the experiments. $\mathrm{HL}$, and $\mathrm{CL}$ designed the research and revised the manuscript critically. All authors read and approved the final manuscript.

\section{Funding}

This research was funded by the National Natural Science Foundation of China (31801707), Postdoctoral Research Grant in Henan Province (001701038), Science-Technology Foundation for High Level Talent of Henan Institute of Science and Technology (2015028) and Plant Protection of Key Discipline Project of Henan province (107020219001/005); the views expressed in this work are the sole responsibility of the authors and do not necessary reflect the views of the funding body. The funding body did not play any role in the design of the study nor in the collection, analysis and interpretation of data, nor in the writing of the manuscript.

\section{Availability of data and materials}

All data generated or analyzed during this study are included in this published article and its supplementary information files. The datasets used and/or analyzed during the current study are available from the corresponding author on reasonable request.

\section{Declarations}

\section{Ethics approval and consent to participate}

The research project and this study have been approved by an ethics committee which found them conform to all national and international guidelines for conservation of endangered species. The plant materials (Money Maker, Zhongshu 4 and Jinpeng 322) used are three common varieties which are not endangered.

\section{Consent for publication}

Not applicable.

\section{Competing interests}

The authors declare that they have no competing interests.

\begin{abstract}
Author details
${ }^{1}$ College of Plant Protection, Henan Agricultural University, Zhengzhou 450002, China. ${ }^{2}$ Postdoctoral Research Base, Henan Institute of Science and Technology, Xinxiang 453001, China. ${ }^{3}$ Henan Engineering Research Center of Crop Genome Editing, Henan Institute of Science and Technology, Xinxiang 453001, China. ${ }^{4}$ Key Laboratory of Plant Genetics and Molecular Breeding, Zhoukou Normal University, Zhoukou 466000, China. ${ }^{5}$ College of Biological Engineering, Henan University of Technology, Zhengzhou 450001, China.
\end{abstract}

Received: 22 March 2021 Accepted: 10 November 2021

Published online: 20 November 2021

\section{References}

1. Zhirnov IV, Trifonova EA, Kochetov AV, Shumny VK. Virus-induced silencing as a method for studying gene functions in higher plants. Genetika. 2015:51(5):558-67. https://doi.org/10.1134/s1022795415050099.

2. Robertson D. VIGS vectors for genes silencing: many targets, many tools Annu Rev Plant Biol. 2004;55:495-519. https://doi.org/10.1146/annurev. arplant.55.031903.141803.

3. Burch-Smith TM, Anderson JC, Martin GB, Dinesh-Kumar SP. Applications and advantages of virus-induced gene silencing for gene function studies in plants. Plant J. 2004:39(5):734-46. https://doi.org/10.1111/j.1365 313x.2004.02158.x.
4. Lange M, Yellina AL, Orashakova S, Becker A. Virus-induced gene silencing (VIGS) in plants: an overview of target species and the virus-derived vector systems. Methods Mol Biol (Clifton, NJ). 2013;975:1-14. https://doi. org/10.1007/978-1-62703-278-0_1.

5. Fu D, Zhu B, Zhu H, Jiang W, Luo Y. Virus-induced gene silencing in tomato fruit. Plant J. 2005;43(2):299-308. https://doi.org/10.1111/j.1365$313 \times .2005 .02441 . x$.

6. Brigneti G, Martín Hernández AM, Jin H, Chen J, Baulcombe DC, Baker $B$, et al. Virus-induced gene silencing in Solanum species. Plant J. 2004;39(2):264-72. https://doi.org/10.1111/j.1365-313x.2004.02122.x.

7. Liu Y, Schiff M, Dinesh-Kumar SP. Virus-induced gene silencing in tomato. Plant J. 2002;31(6):777-86. https://doi.org/10.1046/j.1365-313x.2002. 01394.x.

8. Ma H, Pei D, Geng H, Wang L, Wang W, Li C. Viruse-induced gene silencing in tomato. Acta Bot Sin. 2009;29(8):1531-7.

9. Kim J, Park M, Jeong ES, Lee JM, Choi D. Harnessing anthocyanin-rich fruit: a visible reporter for tracing virus-induced gene silencing in pepper fruit. Plant Methods. 2017;13(1):3. https://doi.org/10.1186/s13007-016-0151-5.

10. Ryu C, Anand A, Kang L, Mysore KS. Agrodrench: a novel and effective agroinoculation method for virus-induced gene silencing in roots and diverse Solanaceous species. Plant J. 2004;40(2):322-31. https://doi.org/ 10.1111/j.1365-313x.2004.02211.x.

11. Todd AT, Liu E, Polvi SL, Pammett RT, Page JE. A functional genomics screen identifies diverse transcription factors that regulate alkaloid biosynthesis in Nicotiana benthamiana. Plant J. 2010;62(4):589-600. https:// doi.org/10.1111/j.1365-313x.2010.04186.x.

12. George GM, Bauer R, Blennow A, Kossmann J, Lloyd JR. Virus-induced multiple gene silencing to study redundant metabolic pathways in plants: silencing the starch degradation pathway in Nicotiana benthamiana. Biotechnol J. 2012;7(7):884-90. https://doi.org/10.1002/biot.201100469.

13. Burch-Smith TM, Schiff M, Liu Y, Dinesh-Kumar SP. Efficient virus-induced gene silencing in Arabidopsis. Plant Physiol. 2006;142(1):21-7. https://doi. org/10.1104/pp.106.084624.

14. Hileman LC, Drea S, Martino G, Litt A, Irish VF. Virus-induced gene silencing is an effective tool for assaying gene function in the basal eudicot species Papaver somniferum (opium poppy). Plant J. 2005;44(2):334-41. https://doi.org/10.1111/j.1365-313X.2005.02520.X.

15. Gao X, Britt RC Jr, Shan L, He P. Agrobacterium-mediated virus-induced gene silencing assay in cotton. J Vis Exp. 2011;54:e2938. https://doi.org/ 10.3791/2938.

16. Adhikary D, Khatri Chhetri U, Tymm FJM, Murch SJ, Deyholos MK. A virus-induced gene-silencing system for functional genetics in a betalainic species, Amaranthus tricolor (Amaranthaceae). Appl Plant Sci. 2019;7(2):e1221. https://doi.org/10.1002/aps3.1221.

17. Zhang J, Yu D, Zhang Y, Liu K, Xu K, Zhang F, et al. Vacuum and cocultivation agroinfiltration of (germinated) seeds results in tobacco rattle virus (TRV) mediated whole-plant virus-induced gene silencing (VIGS) in wheat and maize. Front Plant Sci. 2017;8:393. https://doi.org/10.3389/fpls. 2017.00393.

18. Scholthof KG, Adkins S, Czosnek H, Palukaitis P, Jacquot E, Hohn T, et al. Top 10 plant viruses in molecular plant pathology. Mol Plant Pathol. 2011;12(9):938-54. https://doi.org/10.1111/j.1364-3703.2011.00752.x.

19. M L. Screening for TYLCV-resistant plants using whitefly mediated inoculation. In: Czosnek H, editor. Tomato Yellow Leaf Curl Virus Disease. The Netherlands: Springer; 2007. p. 329-42.

20. Gaba V, Lapidot M, Gal-On A. Hand gun-mediated inoculation of plants with viral pathogens for mechanistic studies. Methods Mol Biol. 2013;940:53-62. https://doi.org/10.1007/978-1-62703-110-3_5.

21. Hull R. Mechanical inoculation of plant viruses. Curr Protoc Microbiol. 2009;13(1). https://doi.org/10.1002/9780471729259.mc16b06s13.

22. Gal-On A, Meiri E, Huet H, Hua WJ, Raccah B, Gaba V. Particle bombardment drastically increases the infectivity of cloned DNA of zucchini yellow mosaic potyvirus. J Gen Virol. 1995;76(Pt 12):3223-7. https://doi. org/10.1099/0022-1317-76-12-3223.

23. Sundaresha S, Sreevathsa R, Balol GB, Keshavareddy G, Rangaswamy KT, Udayakumar M. A simple, novel and high efficiency sap inoculation method to screen for tobacco streak virus. Physiol Mol Biol Pla. 2012;18(4):365-9. https://doi.org/10.1007/s12298-012-0125-7.

24. Abdallat AMA, Debei HSA, Asmar H, Misbeh S, Quraan A, Kvarnheden A. Research an efficient in vitro-inoculation method for tomato. Virol J. 2010;7:84. https://doi.org/10.1186/1743-422X-7-84. 
25. Xie Y, Jiang T, Zhou X. Agroinoculation shows tobacco leaf curl Yunnan virus is a monopartite begomovirus. Eur J Plant Pathol. 2006;115:369-75. https://doi.org/10.1007/s10658-006-9021-8.

26. Senthil-Kumar M, Hema R, Anand A, Kang L, Udayakumar M, Mysore KS. A systematic study to determine the extent of gene silencing in Nicotiana benthamiana and other Solanaceae species when heterologous gene sequences are used for virus-induced gene silencing. New Phytol. 2007;176(4):782-91. https://doi.org/10.1111/j.1469-8137.2007.02225.x.

27. Shimizu-Sato S, Mori H. Control of outgrowth and dormancy in axillary buds. Plant Physilol. 2001;127:1405-13. https://doi.org/10.1104/pp. 010841.

28. Xu K, Huang X, Wu M, Wang Y, Chang Y, Liu K, et al. A rapid, highly efficient and economical method of agrobacterium-mediated in planta transient transformation in living onion epidermis. PLoS One. 2014;9(1):e83556. https://doi.org/10.1371/journal.pone.0083556.
29. Zhang H, Gong H, Zhou X. Molecular characterization and pathogenicity of tomato yellow leaf curl virus in China. Virus Genes. 2009;39(2):249-55. https://doi.org/10.1007/s11262-009-0384-8.

30. Huckelhoven R, Fodor J, Preis C, Kogel KH. Hypersensitive cell death and papilla formation in barley attacked by the powdery mildew fungus are associated with hydrogen peroxide but not with salicylic acid accumulation. Plant Physilol. 1999;119(4):1251-60. https://doi.org/10.1104/pp. 119.4.1251

\section{Publisher's Note}

Springer Nature remains neutral with regard to jurisdictional claims in published maps and institutional affiliations.
Ready to submit your research? Choose BMC and benefit from:

- fast, convenient online submission

- thorough peer review by experienced researchers in your field

- rapid publication on acceptance

- support for research data, including large and complex data types

- gold Open Access which fosters wider collaboration and increased citations

- maximum visibility for your research: over $100 \mathrm{M}$ website views per year

At BMC, research is always in progress.

Learn more biomedcentral.com/submissions 